\title{
Peningkatan Kemampuan Dalam Menyelesaikan Persamaan Linier Satu Variabel (PLSV) dengan Metode STAD Pada Siswa Kelas VII SMP
}

\author{
Nurul A'yuni \\ SMPN 1 Mlarak \\ Surel : nurulayuni7102@gmail.com
}

\begin{abstract}
Abstrak
Kesulitan pembelajaran dalam menyelesaikan Persamaan Linear Satu Variabel (PLSV) sering ditemui dalam pembelajaran Matematika. Pada penelitian ini permasalahan pembelajaran diselesaikan dengan menggunakan metode STAD. Penelitian ini menggunakan pendekatan Penelitian Tindakan Kelas (PTK) untuk analisis. Jumlah responden yang diteliti 32 siswa dengan rincian 14 peserta didik laki-laki dan 18 peserta didik perempuan. Penerapan pembelajaran dengan metode STAD mampu menigkatkan aktivitas belajar siswa sebab melibatkan siswa secara aktif dan aktivitas siswa dalam pembelajaran juga meningkat, yang mana hal ini juga dibuktikan dari skor yang meningkat pada setiap siklusnya yaitu pada siklus I dalam kategori baik dan amat baik dengan persentase $25 \%$ sedangkan meningkat pada siklus II dengan persentase $62,5 \%$ dan pada siklus III menjadi 81,25\%.
\end{abstract}

Kata kunci : Pembelajaran matematika, STAD, Persamaan Linear Satu Variabel.

\section{A. Latar Belakang Masalah}

Pada pembelajaran Matematika seorang guru masih sering menemui kesulitan dalam memilih dan menerapkan metode mengajar, serta pendekatan apa yang sesuai dalam proses pembelajarannya yang akibatnya pembelajaran menjadi tidak menarik bagi anak. Terutama pada mata pelajaran Matematika, yang dalam penyampaian materi di kelas, seorang guru harus pandai memlih metode yang tepat sesuai dengan kompetensi yang diajarkan. Hal ini tentunya akan berpengaruh terhadap kelancaran proses pembelajaran dikelas dan suasana kelas menjadi kurang hidup dan tentunya berpengaruh terhadap rendahnya pemahaman konsep yang akhirnya tidak tercapainya standar ketuntasan minimal yang telah ditentukan.

Untuk mengatasi permasalahan ini maka diperlukan kreatifitas guru untuk menjadikan pembelajaran Matematika menjadi lebih menarik sehingga aktifitas belajar siswa meningkat. Tentunya dengan tetap memperhatikan antara kompetensi yang diajarkan dengan metode mengajar yang sesuai dengan kompetensi tersebut. Berdasar kenyataan dilapangan yaitu hasil Penilaian Harian siswa klas VIIA SMPN 1 Mlarak tahun lalu, pada KD menyelesaiakan Persamaan Linier Satu Variabel (PLSV) menunjukkan bahwa pemahaman siswa 
dalam hal menyelesaikan Persamaan Linier Satu Variabel (PLSV) masih rendah artinya hasil nilai dalam Penilaian Harian $75 \%$ masih dibawah KKM. Rendahnya pemahaman siswa terhadap materi ini karena siswa masih bingung atau siswa kurang memahami materi tersebut.

Oleh sebab itu permasalahan diatas perlu segera diatasi karena dengan pengalaman belajar yang kurang optimal maka akan mempengaruhi hasil juga yaitu kurang optimal. Oleh karena itu peneliti sekaligus guru memilih teknik/metode pembelajaran yang dapat diyakini dapat mengatasi masalah tersebut. Dalam hal ini untuk memecahkan masalah tersebut peneliti (guru) mengadakan Penelitian Tindakan Kelas (PTK) dengan judul "Peningkatan Kemampuan dalam menyelesaikan Persamaan Linier Satu Variabel (PLSV) dengan metode STAD pada siswa klas VIIA SMP Negeri 1 Mlarak Tahun Pelajaran 2018/2019". Melalui penelitian ini peneliti (guru) berharap hasil belajar siswa dalam meningkatkan kemampuan menyelesaikan Persamaan Linier Satu Variabel (PLSV) akan meningkat yaitu $80 \%$ siswa mendapat nilai diatas KKM.

\section{B. METODE PENELITIAN}

Penelitian tindakan kelas yang berjudul "Peningkatan Kemampuan dalam menyelesaikan Persamaan Linier Satu Variabel (PLSV) dengan metode STAD pada siswa klas VIIA SMP Negeri 1 Mlarak Tahun Pelajaran 2018/2019” ini dilaksanakan di SMP Negeri 1 Mlarak. SMP Negeri 1 Mlarak terletak di Jalan Raya Mlarak No. 2 tepatnya Desa Joresan Kecamatan Mlarak Kabupaten Ponorogo. Kelas VII A SMP Negeri 1 Mlarak merupakan subjek penelitian. Jumlah siswa di kelas ini 32 peserta didik terdiri atas 14 peserta didik laki-laki dan 18 peserta didik perempuan. Penelitian dilaksanakan pada semester 1 tahun pelajaran 2018/2019.

\section{PEMBAHASAN}

Kegiatan yang dilakukan guru/peneliti pada refleksi awal ini adalah menentukan deskripsi situasi dan materi berisi rekaman hasil kemampuan masing-masing peserta didik. Kemudian dari deskripsi tersebut dapat ditarik satu permasalahan yang timbul, yaitu minat dan kemampuan belajar Matematika peserta didik kelas VII A SMP Negeri 1 Mlarak rendah. Kemampuan ini tidak hanya disbanding dengan peserta didik kelas yang lain, tetapi tergolong rendah juga jika dibanding dengan mata pelajaran lainnya. Dalam tes awal sebelum penelitian atas dasar hasil penilaian harian prosestase ketuntasan belajar peserta didik $56,25 \%$ ( 18 peserta didik ) dan sebanyak 14 peserta didik ( $43,75 \%$ ) tidak tuntas dalam proses pembelajaran. Timbulnya masalah ini disebabkan karena guru kurang memberi motivasi kepada peserta didik, guru tidak melibatkan keaktifan peserta didik dalam pembelajaran dan penggunaan metode pembelajaran kurang/tidak bisa menjadikan kreatifitas peserta didik termotivasi.

Dalam pelaksanaannya penelitian ini dilakukan dalam tiga siklus. Setiap siklusnya terdiri atas dua kali tatap muka/pertemuan. Jumlah keseluruhan terdapat enam kali pertemuan dalam penelitian ini. Keseluruhan rangkaian penelitian hasilnya adalah:

\section{SIKLUS I}

Observasi/pengamatan pada tahap ini proses tindakannya dilaksanakan dengan 
menggunakan lembar observasi. Dari observasi ini diadakan penilaian yang tujuannya untuk mengetahui tingkat kemampuan siswa dalam menyelesaikan Persamaan Linier Satu Variabel (PLSV). Kecenderungan ketuntasan belajar digambarkan dalam gambar 1 , berikut ini:

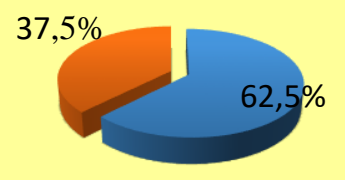

Tun..

\section{Gambar 1. Kecenderungan Ketuntasan Belajar Matematika Siklus I}

Pada gambar diagram diatas dapat dibaca bahwa ketuntasan belajar siswa dalam menyelesaikan Persamaan Linier Satu Variabel (PLSV) yang diamati nilai terendah adalah 58 sedangkan tertinggi 80 . Nilai ratarata siswa adalah 71 dengan tingkat ketuntasan $62,5 \%$ atau sebanyak 20 siswa. Berarti terdapat $62,5 \%$ atau 20 siswa yang mampu mencapai nilai 75 atau lebih. Jadi kemampuan siswa dalam menyelesaikan Persamaan Linier Satu Variabel (PLSV) tergolong masih dalam kategori dan indicator keberhasilan yang ditetapkan sebesar $75 \%$ belum terpenuhi sehingga kemampuan siswa harus ditingkatkan pada pertemuan selanjutnya.

Langkah-langkah pembelajaran yang telah dilakukan peneliti/guru pada dua pertemuan pertama pada siklus I sudah tepat karena dalam penyampaian materi selalu menunjukkan aspek-aspek yang diamati. Berdasarkan hasil dari pengamatan oleh observer, beberapa hal yang perlu diperbaiki pada saat melakukan pembelajaran di kelas adalah:

\section{Tabel 1. Perbaikan yang harus dilakukan} tiap pertemuan

\begin{tabular}{|c|c|c|}
\hline $\begin{array}{l}\text { Yang } \\
\text { melakukan } \\
\text { Perbaikan }\end{array}$ & & Perbaikan yang harus dilakukan \\
\hline \multirow{3}{*}{ Peneliti/guru } & 1 & $\begin{array}{l}\text { Ketika siswa mengerjakan soal, guru kurang tegas } \\
\text { dalam mengontrol waktu. }\end{array}$ \\
\hline & 2 & $\begin{array}{l}\text { Guru masih mendominasi aktifitas di kelas } \\
\text { sehingga peserta didik cenderung pasif. }\end{array}$ \\
\hline & 3 & $\begin{array}{l}\text { Belum memberi perhatian secara merata terhadap } \\
\text { peserta didik. }\end{array}$ \\
\hline \multirow{3}{*}{$\begin{array}{l}\text { Peserta } \\
\text { didik }\end{array}$} & 1 & $\begin{array}{l}\text { Peserta didik banyak yang tidak dapat } \\
\text { menyelesaikan tugas tepat waktu. }\end{array}$ \\
\hline & 2 & $\begin{array}{l}\text { Peserta didik kurang berani dalam mengemukakan } \\
\text { pendapat di kelas sehingga banyak yang } \\
\text { pasif/diam. }\end{array}$ \\
\hline & 3 & Hanya beberapa peserta didik yang selalu aktif. \\
\hline
\end{tabular}

Refleksi hasil pengamatan siklus I penelitian ini adalah :

a. Belum nampak keaktifan dari peserta didik artinya hanya ada beberapa siswa yang berani mengemukakan pendapat.

Dari table 4.2 dapat dilihat bahwa aktifitas peserta didik dengan kategori baik hanya mencapai $25 \%$ atau sejumlah 8 peserta didik artinya bahwa perolehan persentase kemajuan belum memenuhi target yang diharapkan yakni lebih dari $75 \%$ peserta didik aktif dalam kegiatan pembelajaran.

b. Kemajuan siswa dalam menyelesaikan Persamaan Linier Satu Variabel (PLSV) dalam berbagai bentuk dan variable dikatakan masih dibawah standar artinya persentase ketuntasan belajar siswa adalah 
$62,5 \%$ masih dibawah yang diharapkan yaitu lebih dari $75 \%$.

c. Pengelolaan pembelajaran dan aktifitas guru sudah sesuai dan tepat, Aspek-aspek yang dijadikan pengamatan sering dimunculkan oleh guru, dan pendekatan kontekstual digunakan sebagai langkahlangkah pembelajaran. Hasil refleksi dari pertemuan pertama digunakan sebagai acuan untuk pembelajaran pada pertemuan kedua.

Hasil refleksi pada siklus I maka untuk siklus II hal-hal yang harus dilakukan guru sebagai peneliti adalah:

a. Pengembangan materi pada tema menentukan penyelesaian Persamaan Linier Satu Variabel (PLSV) pada soal yang lebih bervariasi dengan harapan tingkat berfikir siswa lebih kreatif.

b. Peserta didik dikelompokkan berdasarkan teman duduk terdekat dan tidak diacak.

c. Untuk peserta didik yang belum bisa/mampu untuk menyelesaikan persamaan linier Satu Variabel (PLSV) diberikan bimbingan dan perhatian khusus.

d. Lebih menekankan pada peran serta dan keaktifan peserta didik dalam mengerjakan tugas baik mandiri maupun kelompok sehingga dominasi guru berkurang.

\section{SIKLUS II}

Data kecenderungan ketuntasan belajar siswa siklus II digambarkan dalam gambar 4.3 berikut ini :

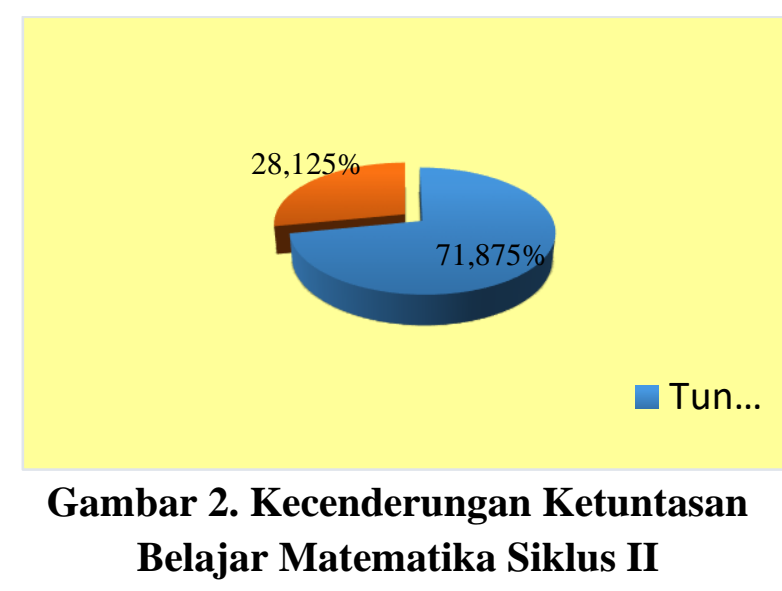

Pada siklus II ini menunjukkan bahwa kemampuan menyelesaikan Persamaan Linier Satu Variabel (PLSV) yang diamati nilai terendah adalah 66 dan perolehan nilai tertinggi adalah 90, untuk nilai rata-rata yang diperoleh pada siklus II yaitu 77 dan pada siklus I nilai rata-rata yaitu 71 , disini terjadi peningkatan nilai rata-rata walaupun peningkatannya belum signifikan. Dengan adanya peningkatan nilai rata-rata dari siklus I ke siklus II ini juga terjadi peningkatan persentase ketuntasan peserta didik yaitu dari siklus I 62,5\% meningkat menjadi 71,875\% pada siklus II. Kenaikannya yang terjadi sebesar $9,375 \%$.

Berarti terdapat 23 siswa yang mampu mencapai nilai 75 atau lebih. Jadi kemampuan pesetra didik dalam menyelesaikan Persamaan Liner Satu Variabel (PLSV) sudah mengalami perubahan yang positif artinya adanya kenaikan jumlah siswa yang mengalami ketuntasan belajar walaupun kenaikannya belum signifikan artinya belum sesuai dengan target keberhasilan yaitu diatas $75 \%$ begitu juga untu pesrta didik yang mempunyai predikat amat baik dan baik juga belum sesuai dengan target keberhasilan yaitu mencapai $75 \%$ maka untuk pertemuan 
berikutnya perlu ditingkatkan lagi. Langkahlangkah pembelajaran yang telah dilakukan peneliti/guru pada siklus II sudah sesuai karena dalam penyampaian materi selalu menunjukkan aspek-aspek yang diamati. Berdasarkan hasil dari pengamatan oleh observer, beberapa hal yang perlu diperbaiki pada saat melakukan pembelajaran di kelas adalah:

Tabel 2. Perbaikan yang harus dilakukan tiap pertemuan

\begin{tabular}{|c|c|l|}
\hline \hline $\begin{array}{c}\text { Yang } \\
\text { melakukan } \\
\text { Perbaikan }\end{array}$ & \multicolumn{2}{|c|}{ Perbaikan yang harus dilakukan } \\
\hline \hline \multirow{2}{*}{ Peneliti/guru } & 1 & $\begin{array}{l}\text { Masih adanya dominasi guru, walaupun } \\
\text { sudah dikurangi. }\end{array}$ \\
\cline { 2 - 4 } & 2 & $\begin{array}{l}\text { Guru dalam menyajikan materi kurang } \\
\text { memberi perhatian terhadap siswa yang } \\
\text { kurang fakus terhadap materi yang } \\
\text { diberikan }\end{array}$ \\
\hline \multirow{2}{*}{ Peserta didik } & 1 & $\begin{array}{l}\text { Dalam menyelesaikan tugas beberapa } \\
\text { peserta didik masih belum tepat waktu. }\end{array}$ \\
\cline { 2 - 4 } & 2 & $\begin{array}{l}\text { Belum semua peserta didik memiliki } \\
\text { keberanian dalam } \\
\text { menyampaikan/mengemukakan pendapat. }\end{array}$ \\
\cline { 2 - 4 } & 3 & $\begin{array}{l}\text { Antusiasme dan keaktifan dalam } \\
\text { pembelajaran belum ada pada peserta } \\
\text { didik. }\end{array}$ \\
\hline \hline
\end{tabular}

Refleksi hasil pengamatan siklus II penelitian ini adalah :

a. Sudah nampak keaktifan dari peserta didik artinya peserta didik sudah mulai berani mengemukakan pendapat walaupun terkadang masih malu-malu namun sudah menunjukkan perkembangan walaupun belum maksimal.
Dari table 4.7 dapat dilihat bahwa aktifitas peserta didik dengan predikat amat baik dan baik sudah mencapai $62,5 \%$ atau sejumlah 20 peserta didik artinya bahwa perolehan persentase kemajuan belum memenuhi target yang diharapkan yakni lebih dari $75 \%$ peserta didik aktif dalam kegiatan pembelajaran.

b. Kemajuan siswa dalam menyelesaikan Persamaan Linier Satu Variabel (PLSV) dalam berbagai bentuk dan variable dikatakan belum maksimal yaitu nilai rata-ratnya siklus I sebesar 71 dan meningkat di siklus II sebesar 77 artinya belum sesuai dengan target indicator keberhasilan yang ditetapkan yaitu 75 . Pada siklus II ini siswa mencapai ketuntasan belajar $71,875 \%$, hal ini telah terjadi peningkatan dalam kenaikan sebesar 9\% dari siklus sebelumnya, berarti ada 23 peserta didik dari 32 peserta didik mencapai ketuntasan. Karena target indicator keberhasilan juga belum tercapai maka peneliti melanjutkan pada siklus berikutnya yaitu siklus III.

c. Pengelolaan pembelajaran dan aktifitas guru sudah sesuai dan tepat, Aspekaspek yang dijadikan pengamatan sering dimunculkan oleh guru, dan sudah sesuai dengan prosedur/urutan dalam pembelajaran dengan metode STAD.

Hasil refleksi pada siklus II maka untuk siklus III hal-hal yang harus dilakukan guru sebagai peneliti adalah : 
a. Pengembangan materi pada siklus III adalah penyelesaian Pertidaksamaan Linier Satu Variabel (PtLSV).

b. Peserta didik dikelompokkan berdasarkan pada teman duduk sebangku dan terdekat.

c. Untuk peserta didik yang belum bisa/mampu untuk menyelesaikan pertidaksamaan linier Satu Variabel (PtLSV) diberikan bimbingan dan perhatian khusus.

d. Mendidik anak untuk saling membantu dan kerjasama dengan temannya yang belum bias.

e. Guru tidak bosan untuk mengingatkan pada peserta didik untuk selalu teliti dalam mengerjakan tugas/soal.

\section{SIKLUS III}

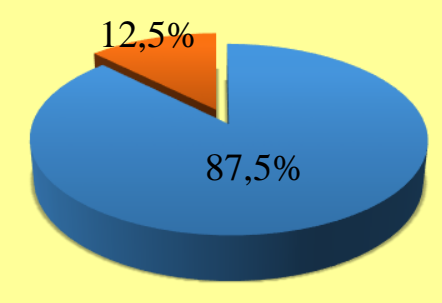

Tun...

\section{Gambar 3. Kecenderungan Ketuntasan Belajar Matematika Siklus III}

Pada siklus III ketuntasan belajar siswa dalam pembelajaran Matematika dalam kemampuan menyelesaikan Pertidaksamaan Linier Satu Variabel (PtLSV) sudah menunjukkan perubahan yang signifikan yaitu nilai terendah adalah 72 dan perolehan nilai tertinggi adalah 90. Adapun nilai ratarata pada siklus III yaitu 80 yang mana pada siklus II nilai rata-rata hanya mencapai 77 hal ini terjadi peningkatan perolehan nilai ratarata, dengan adanya peningkatan nilai ratarata maka terjadi pula peningkatan persentase ketuntasan belajar siswa dari siklus II sebesar $71,875 \%$ menjadi $87,5 \%$ pada siklus III, meningkat sebesar $15,625 \%$.

Berarti terdapat 28 siswa yang mampu mencapai nilai 75 atau lebih. Jadi kemampuan siswa dalam menyelesaikan Persamaan Liner Satu Variabel (PLSV) yang diamati indicator keberhasilannya sudah terpenuhi yaitu sudah melebihi ketetapan yang ditetapkan yaitu $75 \%$. Begitu juga untuk predikat amat baik dan baik bagi peserta didik sudah mencapai $75 \%$, artinya sudah memenuhi indicator keberhasilan keaktifan siswa dalam pembelajajaran yaitu $75 \%$. Oleh sebab itu dalam penelitian ini dihentikan sampai poada siklus III sesuai rencana awal.

Langkah-langkah pembelajaran pada pertemuan siklus III sudah dilaksanakan oleh guru sebagai peneliti dengan tepat, yakni seringnya/selalu menunjukkan aspek-aspek yang diamati. Berdasarkan hasil dari pengamatan oleh observer, beberapa hal yang perlu diperbaiki pada saat melakukan pembelajaran di kelas adalah:

Tabel 3. Perbaikan yang harus dilakukan tiap pertemuan menurut pendapat observer

\begin{tabular}{|c|c|}
\hline \hline $\begin{array}{c}\text { Yang } \\
\text { melakukan } \\
\text { Perbaikan }\end{array}$ & Perbaikan yang harus dilakukan \\
\hline \hline
\end{tabular}




\begin{tabular}{|c|c|l|}
\hline \multirow{5}{*}{ Peneliti/guru } & 1 & $\begin{array}{l}\text { Masih adanya dominasi guru, walaupun } \\
\text { sudah dikurangi. }\end{array}$ \\
\cline { 2 - 4 } & 2 & $\begin{array}{l}\text { Guru dalam menyajikan materi kurang } \\
\text { memberi perhatian terhadap siswa yang } \\
\text { kurang fakus terhadap materi yang } \\
\text { diberikan }\end{array}$ \\
\hline \multirow{5}{*}{$\begin{array}{c}\text { Peserta } \\
\text { didik }\end{array}$} & 1 & $\begin{array}{l}\text { Dalam menyelesaikan tugas beberapa } \\
\text { peserta didik masih belum tepat waktu. }\end{array}$ \\
\cline { 2 - 4 } & 2 & $\begin{array}{l}\text { Belum semua peserta didik memiliki } \\
\text { keberanian } \\
\text { menyampaikan/mengemukakan } \\
\text { pendapat. }\end{array}$ \\
\cline { 2 - 4 } & 3 & $\begin{array}{l}\text { Antusiasme dan keaktifan dalam } \\
\text { pembelajaran belum ada pada peserta } \\
\text { didik. }\end{array}$ \\
\cline { 2 - 4 } & 4 & $\begin{array}{l}\text { Kekompakan anggota kelompok masih } \\
\text { kurang }\end{array}$ \\
\hline \hline
\end{tabular}

Refleksi hasil pengamatan siklus III penelitian ini adalah:

a. Peserta didik sudah banyak yang aktif artinya peserta didik sudah berani mengemukakan pendapat dengan bahasanya sendiri dan sudah menunjukkan kemajuan yannnggg signifikan. Dari table 4.12 terdapat $81,25 \%$ atau 26 siswa sudah aktif dalam kegitan pembelajaran ini berarti target $75 \%$ siswa aktif dalam kegiatan pembelajaran terpenuhi atau sesuai dengan indicator keberhasilan.

b. Kemampuan siswa dalam menyelesaikan Persamaan Linier satu Variabel (PLSV) yang diamati sudah mengalami kemajuan yaitu dari ketuntasan minimal yang awalnya $62,5 \%$ meningkat menjadi $87,5 \%$, sehingga target indicator keberhasilan terpenuhi.

c. Dalam pengelolaa terhadap pembelajaran dan juga aktifitas guru pada saat pembelajaran sudah sesuai dan tepat karena sudah sesuai dengan prosedur dalam pembelajaran dengan metode STAD.

Hasil refleksi pada siklus III sudah selesai dan dihentikan karena sudah sesuai dengan tujuan pembelajaran dan indicator keberhasilan telah tercapai maka peserta didik diminta untuk mengisi angket secara tertutup yang hasilnya bias dilihat pada table 4:

Tabel 4. Hasil angket peserta didik terhadap pembelajaran dengan metode STAD

\begin{tabular}{|c|l|c|c|}
\hline \hline No. & \multicolumn{1}{|c|}{ Butir Angket } & $\begin{array}{c}\text { Setuju } \\
(\%)\end{array}$ & $\begin{array}{c}\text { Tidak } \\
\text { Setuju } \\
(\%)\end{array}$ \\
\hline \hline 1 & $\begin{array}{l}\text { Penggunaan metode } \\
\text { pembelajaran dengan STAD } \\
\text { menyenangkan karena kita } \\
\text { bisa tukar pendapat dengan } \\
\text { teman }\end{array}$ & 100 & 0 \\
\hline 2 & $\begin{array}{l}\text { Materi/Bahan ajar } \\
\text { pembelajaran dan cara } \\
\text { penyelesaian tugas lebih } \\
\text { mudah/gampang diingat } \\
\text { dengan metode STAD }\end{array}$ & 55 & 55 \\
\hline 3 & $\begin{array}{l}\text { Penggunaan metode } \\
\text { pembelajaran dengan STAD } \\
\text { menyenangkan karena kita } \\
\text { bisa tukar pendapat dengan } \\
\text { teman }\end{array}$ & $\begin{array}{l}\text { Penggunaan metode } \\
\text { pembelajaran dengan STAD } \\
\text { menyenangkan karena kita } \\
\text { bisa tukar pendapat dengan } \\
\text { teman }\end{array}$ & $\begin{array}{l}\text { Penggunaan metode } \\
\text { pembelajaran dengan STAD } \\
\text { menyenangkan karena kita } \\
\text { bisa tukar pendapat dengan } \\
\text { teman }\end{array}$ \\
\hline \hline
\end{tabular}

\section{Analisis Data}

Atas dasar analisa data penelitian, maka hasilnya dapat disimpulkan bahwa 
kemampuan keamampuan siswa dalam menyelesaikan Persamaan Linie Satu variable (PLSV) yang diamati pada siswa kelas VII A SMP Negeri 1 Mlarak Semester 1 Tahun Pelajaran 2018/2019 dapat ditingkatkan melalui metode STAD.

Tabel 5. Rekapitulasi Hasil Penilaian Matematika Peserta Didik

\begin{tabular}{|l|c|c|c|}
\hline \hline $\begin{array}{c}\text { Data Penilaian } \\
\text { Penilitian }\end{array}$ & $\begin{array}{c}\text { Siklus } \\
\text { I }\end{array}$ & $\begin{array}{c}\text { Siklus } \\
\text { II }\end{array}$ & $\begin{array}{c}\text { Siklus } \\
\text { III }\end{array}$ \\
\hline \hline Rentang Nilai & $0-100$ & $0-100$ & $0-100$ \\
\hline Nilai Tertinggi & 80 & 90 & 90 \\
\hline Nilai Terendah & 58 & 66 & 72 \\
\hline Rata-rata & 71 & 77 & 80 \\
\hline \hline
\end{tabular}

Peranan pembelajaran STAD dalam meningkatkan kemampuan menyelesaikan Persamaan Linier satu variable (PLSV) yang dapat dilihat dari meningkatnya nilai rata-rata dalam setiap siklusnya dengan hasil untuk siklus I nilai rata-rata 71 meningkat menjadi 77 untuk siklus II dan untuk nilai rata-rata sklus III naik juga menjadi 80. Dengan adanya kenaikan nilai rata-rata pada setiap siklusnya maka terjadi juga kenaikan persentase ketuntasan belajar siswa pada setiap siklusnya yaitu dari $62,5 \%$ pada siklus I menjadi $71,875 \%$ pada siklus II dan $87,5 \%$ pada siklus III. Penerapan pembelajaran dengan metode STAD mampu menigkatkan aktivitas belajar siswa sebab melibatkan siswa secara aktif dan aktivitas siswa dalam pembelajaran juga meningkat, yang mana hal ini juga dibuktikan dari skor yang meningkat pada setiap siklusnya yaitu pada siklus I dalam kategori baik dan amat baik dengan persentase $25 \%$ sedangkan meningkat pada siklus II dengan persentase $62,5 \%$ dan pada siklus III menjadi $81,25 \%$.

Dari pelaksanaan tindakan kelas yang dilakukan di SMP Negeri 1 Mlarak yaitu Penggunaan metode STAD untuk meningkatkan kemampuan menyelesaikan persamaan linier satu variabel (PLSV) pada siswa kelas VIIA Semester ganjil tahun 2018/2019 sebagai berikut :

1. Pelaksanaan siklus pertama

Keaktifan siswa dalam kelompok masih rendah artinya siswa yang kurang aktif masih tergantung pada siswa yang aktif, sehingga dengan demikian menyebabkan nilai uji kompetensi atau penilaian harian rendah artinya masih banyak siswa yang memperoleh nilai dibawah KKM. Disini ditunjukkan mean skor yang dicapai pada siklus I adalah 71 sedangkan ketuntasan yang dicapai $62,5 \%$.

2. Pelaksanaan siklus kedua

Ketika peserta didik berada pada siklus II, dapat ditunjukkan bahwa pembelajaran berlangsung aktif dan dalam kegiatan kelompok siswa yang semula belum aktif sudah menunjukkan keaktifannya walaupun belum maksimal Hal ini akhirnya bisa dilihat pada hasil nilai dari penilaian hariannya, yaitu mean skor pada siklus I 71 menjadi 77 pada siklus II sedangkan ketuntasan pada siklus I adalah $62,5 \%$ menjadi $71,875 \%$ pada siklus II, hal ini menunjukkan peningkatan walaupun belum signifikan.

3. Pelaksanaan siklus III

Pada tahap siklus III secara umum sudah terlihat adanya peningkatan aktivitas belajar siswa yang maksimal yang ditandai dengan kenaikan mean skor menjadi 80 dan ketuntasannya sudah mencapai $87,5 \%$ yang mana sudah termasuk predikat amat baik dan 
baik. Kenaikan tersebut terjadi karena peserta didik sudah berusaha dengan maksimal sehingga peserta didik dapat menunjukkan kemampuannya, dan mereka sadar bahwa mata pelajaran Matematika sangatlah penting kegunaannya dalam kehidupan nyata atau kehidupan sehari-hari.

Dari uraian diatas yaitu dari perkembangan tiap siklusnya dapat diambil kesimpulan bahwa metode pembelajaran STAD merupakan salah satu metode pembelajaran yang baik atau sesuai dalam pembelajaran Matematika karena terbukti dapat meningkatkan pemahaman siswa terhadap materi yang diberikan. Pelaksanaan tindakan kelas dengan menggunakan metode STAD di SMP Negeri 1 Mlarak Ponorogo masih menmukan kendala-kendala, antara lain :

1. Pada awal pelasanaan pembelajaran anak yang kurang aktif (kurang pandai) akan pasif dan dia tergantung pada siswa yang aktif (siswa yang pandai)

2. Persiapan perencanaan pembelajaran yang lebih matang sangat diperlukan.

3. Guru dituntut harus benar-benar inovatif terhadap proses pembelajaran sehingga nantinya diperoleh hasil yang maksimal.

4. Siswa yang memiliki tipe belajar mendengarkan atau jiwa sosialnya kurang menarik, karena dalam pembelajaran ini dibutuhkan kerjasama yang baik dalam kelompok.

\section{DAFTAR PUSTAKA}

Kementrian Pendidikan dan Kebudayaan Republik Indonesia Tahun 2016, Buku

\author{
Siswa untuk SMP/MTs kelas VII \\ semester 1.
}

Kementrian Pendidikan dan Kebudayaan Republik Indonesia Tahun 2016, Buku guru untuk SMP/MTs kelas VII.

Dr.Suyatno,M.Pd., 2009. Menjelajah Pembelajaran Inovatif, Sidoarjo: Masmedia Buana Pustaka.

J. Dris, 2005. Matematika Jilid I, Jakarta : Piranti Darma Kalokatama.

Depdiknas, 2007. Matematika-Bahan Penyerta, Jakarta : Pusat Teknologi Informasi dan Komunikasi Pendidikan.

Depdiknas, 2005. Materi Pelatihan

Terintegrasi Matematika, Jakarta : Depdiknas RI. Kamus Besar bahasa Indonesia (1997:76) 


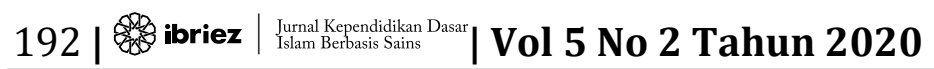

